\title{
Chemical analysis of Punica granatum fruit peel and its in vitro and in vivo biological properties
}

\author{
Kaliyan Barathikannan ${ }^{1}$, Babu Venkatadri', Ameer Khusro', Naif Abdullah Al-Dhabi², Paul Agastian',
} Mariadhas Valan Arasu $^{2^{*}}$, Han Sung $\mathrm{Choi}^{3}$ and Young Ock Kim ${ }^{4^{*}}$

\begin{abstract}
Background: The medical application of pomegranate fruits and its peel is attracted human beings. The aim of the present study was to evaluate the in vitro a-Glucosidase inhibition, antimicrobial, antioxidant property and in vivo anti-hyperglycemic activity of Punica granatum (pomegranate) fruit peel extract using Caenorhabditis elegans.

Methods: Various invitro antioxidant activity of fruit peel extracts was determined by standard protocol. Antibacterial and antifungal activities were determined using disc diffusion and microdilution method respectively. Anti-hyperglycemic activity of fruit peel was observed using fluorescence microscope for in vivo study.

Results: The ethyl acetate extract of $P$. granatum fruit peel (PGPEa) showed a-Glucosidase inhibition upto $50 \%$ at the concentration of IC50 $285.21 \pm 1.9 \mu \mathrm{g} / \mathrm{ml}$ compared to hexane and methanol extracts. The total phenolic content was highest (218.152 $\pm 1.73 \mathrm{mg}$ of catechol equivalents/g) in ethyl acetate extract. PGPEa showed more scavenging activity on 2,2-diphenyl-picrylhydrazyl (DPPH) with IC50 value $302.43 \pm 1.9 \mu \mathrm{g} / \mathrm{ml}$ and total antioxidant activity with IC50 $294.35 \pm 1.68 \mu \mathrm{g} / \mathrm{ml}$. PGPEa also showed a significant effecton lipid peroxidation IC50 $208.62 \pm 1$. $68 \mathrm{\mu g} / \mathrm{ml}$, as well as high reducing power. Among the solvents extracts tested, ethyl acetate extract of fruit peel showed broad spectrum of antimicrobial activity. Ethyl acetate extract supplemented C.elegans worms showed inhibition of lipid accumulation similar to acarbose indicating good hypoglycemic activity. The normal worms compared to test (ethyl acetate extract supplemented) showed the highest hypoglycaemic activity by increasing the lifespan of the worms. GC-MS analysis of PGPEa showed maximum amount of 5-hydroxymethylfurfural and 4-fluorobenzyl alcohol (48.59\%).
\end{abstract}

Conclusion: In the present investigation we observed various biological properties of pomegranate fruit peel. The results clearly indicated that pomegranate peel extract could be used in preventing the incidence of long term complication of diabetics.

Keywords: P. granatum, a-Glucosidase inhibition, Antioxidants activity, Antimicrobial activity, Caenorhabditis elegans, GC-MS analysis

\footnotetext{
*Correspondence: mvalanarasu@gmail.com; kyo9128@korea.kr; ky09128@ gmail.com

2Department of Botany and Microbiology, Addiriyah Chair for Environmental Studies, College of Science, King Saud University, Riyadh 11451, Saudi Arabia ${ }^{4}$ Development of Ginseng and Medical Plants Research Institue, Rural Administration, Eumseong 369-873, Republic of Korea

Full list of author information is available at the end of the article
} 


\section{Background}

Diabetes mellitus is generally characterized by hyperglycemia that leads to disturbances in the metabolism of carbohydrates, lipids and proteins [1]. Chronic inflammation leads to obesity and it may be prevented by avoiding sugar containing food items. Nowadays insulin therapy is encouraged for the prevention of diabetes mellitus, but the therapy has several side effects like insulin resistance [2], anorexia nervosa, brain atrophy etc. Recently, the use of medicinal plants in modern medicine has been increased in order to prevent or to cure diseases [3-6]. At present food safety is an important concern due to the presence of food borne and other clinical pathogens. The quest for new antimicrobials have been taken into account by researchers worldwide due to the emergence of antibiotic resistant organisms and toxicity of synthetic drugs. Herbal plants and their extracts have been investigated in last few years due to the toxicological concerns of synthetic drugs [7, 8]. The secondary metabolites obtained from medicinal plants have also been investigated for their radical scavenging property.

P. granatum Linn. (Pomegranate) is abundantly present in India and belongs to family Punicaceae. Pomegranate peel contains tannins, flavonoids, polyphenols and some anthocyanins such as cyanidins and delphinidins [9]. Extracts from the peels of pomegranate has been proposed to play vital role in various pharmacological activities $[10,11]$. The natural antioxidant food supplement will give the anti- aging process of skin, cells, tissues and organs. Antioxidants are present in certain fruits and vegetables that can protect human cells from oxidative damage and prevent aging of cells and body [12]. It reduces the incidence of tumors and infections. The plant constitutes gallotannic acid and the alkaloid such as isopelletierine, pelletierine, methypelletierine, psuedopelletierine, gallic acid, tannic acie, sugar, cacium oxalate, etc. However, the phytochemical constituents of the plant and antimicrobial activity of this plant have been reported in literature $[13,14]$. It is very important to explore the findings of the research by investigation it in vivo and understanding its interactive effect.

C. elegans is a model organism that can be grown cheaply and in large numbers on plates. The worm is preferred over other model organisms especially mouse because they have a short life cycle of only 2 weeks which reduces the experimental cycles and the behaviour of individual cells can be studied because of its transparent body. Additionally, C. elegans genome have functional counterparts in humans which makes it a convenient model for human diseases especially diabetes study.
The nematode Caenorhabditis elegans contains abundant fat droplets in intestinal and hypodermal tissue. Compared to droplets in mammalian adipose tissue, which can expand to sizes of $100 \mu \mathrm{m}$ [15], C. elegans lipid droplets are small, typically in the size range of $1-1.5 \mu \mathrm{m}$ [16]. C. elegans has a multistep developmental process due to multicellularilty property. Regulation of lipid droplets inside the nematode using potential herbal extracts will yield key insights into the understanding of obesity, diabetes, and other metabolic diseases [17, 18]. From thios point of view, the present study was evaluated to determine antioxidant activity, $\alpha$-Glucosidase activity, antimicrobial and antidiabetic property of pomegranate fruit peel extracts.

\section{Methods}

\section{Collection of plant}

The Healthy fresh pomegranate peel was collected Irula Tribe Women's Welfare Society (ITWWS), Chengalpet, Tamil Nadu, India. The taxonomical identification of the plants was confirmed by Dr. Jeyajothi, botanist from Loyola College, Chennai, India. The plant was deposited under the vocher number LCH-74 in Loyola College, Chennai.

\section{Plant material and extraction}

Peels of $P$. granatum (pomegranate) were shade dried and subsequently powdered. Five hundred grams of powdered peel was soaked in three different solvents (Hexane, ethyl

Table 1 a-Glucosidase inhibition of extracts of Punica granatum (Pomegranate) fruit peal

\begin{tabular}{|c|c|c|}
\hline \multirow{2}{*}{$\begin{array}{l}\text { Sample concentration } \\
(\mu \mathrm{g} / \mathrm{ml})\end{array}$} & \multicolumn{2}{|l|}{ Punica granatum fruit peel } \\
\hline & a-Glucosidase inhibition & $\mathrm{IC} 50(\mu \mathrm{g} / \mathrm{ml})$ \\
\hline \multicolumn{3}{|l|}{ Hexane } \\
\hline 100 & $33.6 \pm 1.9$ & $349 \pm 2.20$ \\
\hline 300 & $43.5 \pm 2.0$ & \\
\hline 500 & $69.1 \pm 2.3$ & \\
\hline \multicolumn{3}{|l|}{ Ethyl Acetate } \\
\hline 100 & $38.7 \pm 1.98$ & $285 \pm 1.98$ \\
\hline 300 & $51.5 \pm 1.91$ & \\
\hline 500 & $75.6 \pm 2.03$ & \\
\hline \multicolumn{3}{|l|}{ Methanol } \\
\hline 100 & $20.7 \pm 2.2$ & $400 \pm 2.58$ \\
\hline 300 & $38.1 \pm 1.8$ & \\
\hline 500 & $62.0 \pm 2.01$ & \\
\hline \multicolumn{3}{|l|}{ Std (Acarbose) } \\
\hline 100 & $41.8 \pm 1.60$ & $205 \pm 2.21$ \\
\hline 300 & $56.54 \pm 1.91$ & \\
\hline 500 & $80.75 \pm 2.08$ & \\
\hline
\end{tabular}

Each value represents the mean \pm SEM of triplicate experiments 


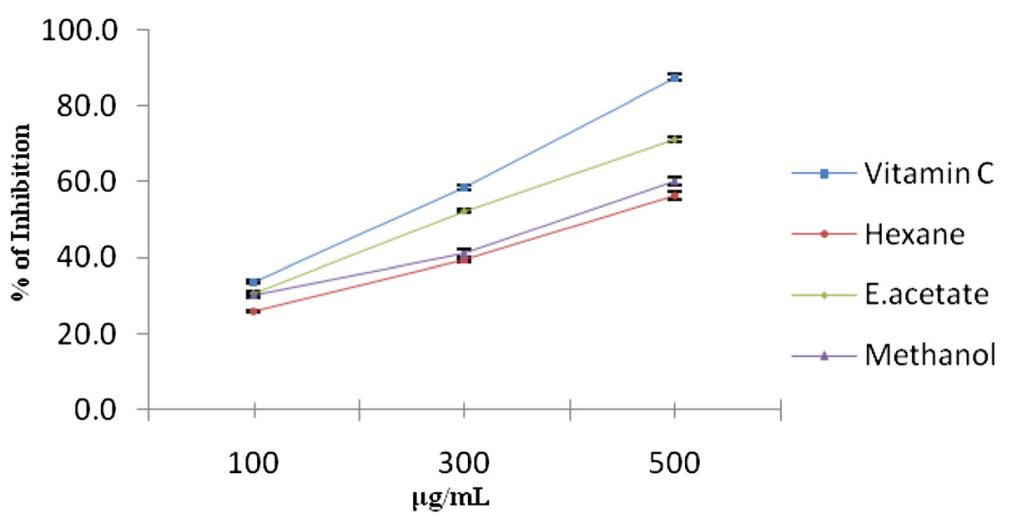

Fig. 1 DPPH scavenging effect of hexane, ethyl acetate, and methanol extracts of Punica granatum (Pomegranate) fruit peel extracts and Vitamin $C$ at different concentrations $(100-500 \mu \mathrm{g} / \mathrm{ml})$. Each value represents the mean \pm standard deviation of triplicate experiments

acetate and methanol) at room temperature for $72 \mathrm{~h}$ in rotatory shaker $(120 \mathrm{rpm})$. The powder and solvent were taken in the ratio of 1:3. The filtrates were further concentrated under reduced pressure at $40{ }^{\circ} \mathrm{C}$ and stored in a refrigerator at $2-8{ }^{\circ} \mathrm{C}$ for use in subsequent experiments.

\section{a-Glucosidase inhibition of solvent extracts}

To analyse the $\alpha$-Glucosidase inhibition, standard methodology was followed with some modifications $[19,20]$.

\section{Total phenolic content (TPC)}

To analyse the total level of phenolic components, Folin-Ciocalteau method was followed with some modifications [20].

DPPH radical scavenging assay of $P$. granatum fruit peel DPPH quenching ability of $P$. granatum fruit peel hexane ether, ethyl acetate and methanol extracts was measured according to Hanato et al. [21].
Evaluation total antioxidant activity of $P$. granatum fruit peel

The total antioxidant activity of $P$. granatum fruit peel was determined according to the method of [22].

\section{Lipid peroxidation assay}

The evaluated the lipid peroxide properties of the extracts thiobarbituric acid method was followed [20].

\section{Reducing power activity of $P$. granatum fruit peel}

The invitro reducing power activies of the different concnetrations of the plant extract were evaluated by following the standard methodology [3].

\section{Assessment of antimicrobial activity of $P$. granatum fruit peel Test organisms}

The following bacterial cultures were used to perform antibacterial test using MTCC and ATCC cultures: Escherichia coli MTCC 441, Klebsiella pneumonia

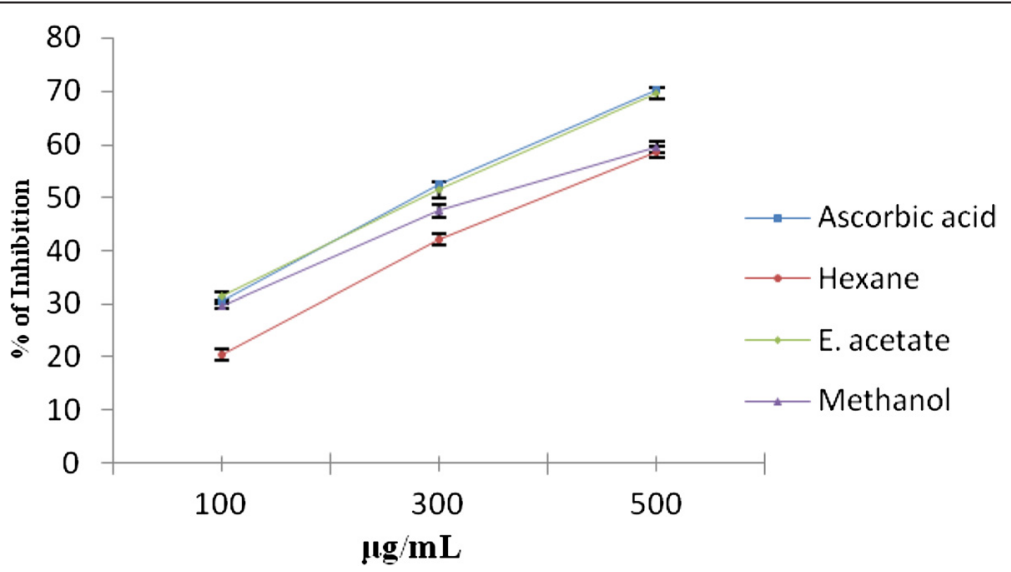

Fig. 2 Total antioxidant activity of hexane, ethyl acetate, and methanol extracts of Punica granatum (Pomegranate) fruit peel extracts and Vitamin $\mathrm{C}$ at different concentrations $(100-500 \mu \mathrm{g} / \mathrm{ml})$. Each value represents the mean \pm standard deviation of triplicate experiments 


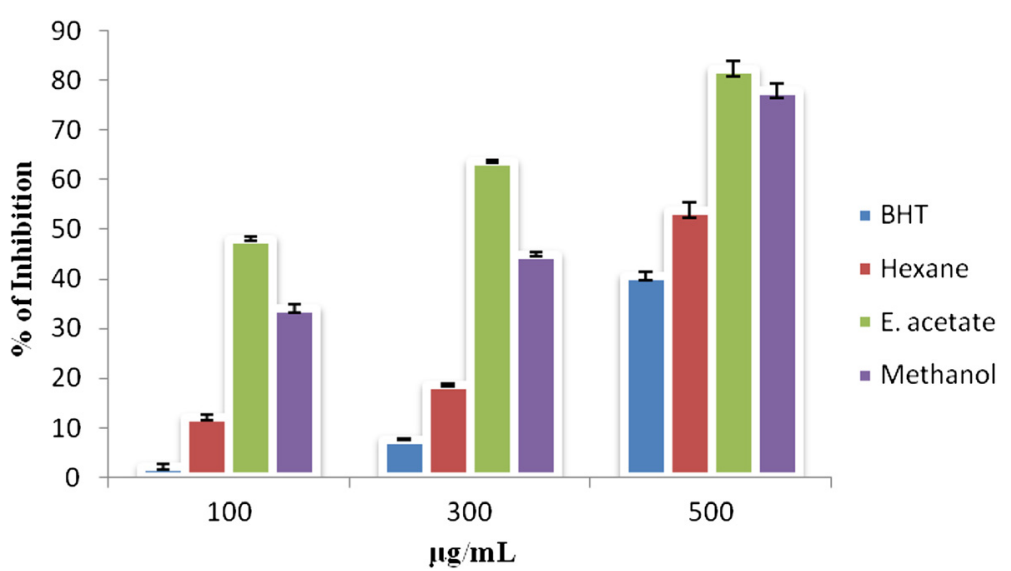

Fig. 3 Reducing power of hexane, ethyl acetate, methanol extracts of Punica granatum (Pomegranate) fruit peel extractsand BHT at different concentrations $(100-500 \mu \mathrm{g} / \mathrm{ml})$. Each value represents the mean \pm standard deviation of triplicate experiments

ATCC 1705, Streptomyces diastaticus MTCC 1394 and Enterococcus faecalis MTCC 439.

Clinical isolates: Enterobacter aerogenes, Klebsiella pneumoniae, Enterococcus faecalis, Staphylococcus epidermidis, Mycobacterium smegmatis and Escherichia coli and other fungal strains.

\section{Disc diffusion method}

The inhibition activity of the extracts against various pathogenic bacteria were determined by folling the standard methodology [3]. Plates were incubated overnight at $37{ }^{\circ} \mathrm{C}$ and then the zone of inhibition was measured in $\mathrm{mm}$. All experiments were repeated in triplicate.

\section{Antifungal assays using broth micro dilution method} Antifungal activity was performed according to the standard reference method [23]. The antifungal agent, fluconazole was used as positive control and DMSO was used as negative control.

\section{C. elegans strains and culture conditions}

The Bristol N2 (wild-type) C. elegans strain was used in this study and was obtained from Department of Genetic engineering, Madurai Kamaraj University, Tamil Nadu. It was maintained at $20{ }^{\circ} \mathrm{C}$ on nematode growth medium (NGM) agar plates. Plates were supplemented with Escherichia coli OP50 as nematode feed.

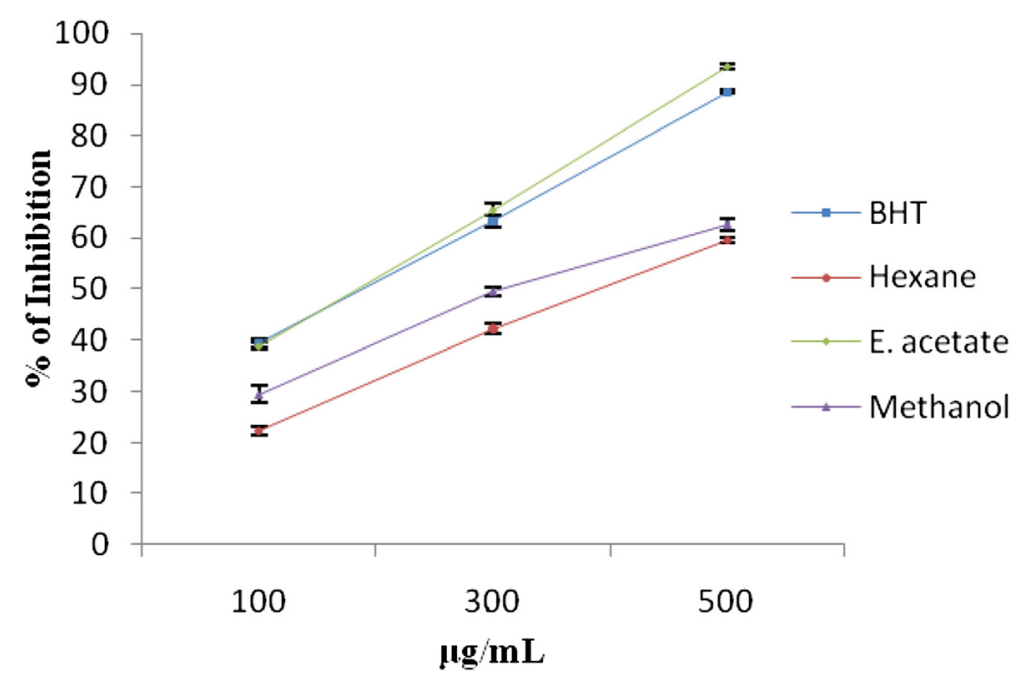

Fig. 4 Lipid peroxidation scavenging effect of hexane, ethyl acetate, methanol extracts of Punica granatum (Pomegranate) fruit peel extracts and BHT at different concentrations $(100-500 \mu \mathrm{g} / \mathrm{ml})$. Each value represents the mean \pm standard deviation of triplicate experiments 
Table 2 Antibacterial activities of crude extracts of Punica granatum (Pomegranate) fruit peel

\begin{tabular}{|c|c|c|c|c|}
\hline \multirow[t]{2}{*}{ Name of the pathogen } & \multicolumn{3}{|c|}{$\begin{array}{l}\text { Antibactrerial activity of extract }(2.5 \mathrm{mg} / \mathrm{ml}) \\
\text { Zone of inhibition }(\mathrm{mm})\end{array}$} & \multirow[t]{2}{*}{$\begin{array}{l}\text { Streptomycin } \\
(10 \mu \mathrm{g} / \mathrm{disc})\end{array}$} \\
\hline & Hexane & Ethyl Acetate & Methanol & \\
\hline \multicolumn{5}{|l|}{ MTCC Isolates } \\
\hline Escherichia coli MTCC 441 & $8 \pm 1$ & $16 \pm 1$ & $13 \pm 2$ & $24 \pm 1$ \\
\hline Klebsiella pneumoniae ATCC 1705 & $6 \pm 1$ & $9 \pm 1$ & $7 \pm 1$ & $11 \pm 2$ \\
\hline Streptomyces diastaticus MTCC 1394 & $13 \pm 1$ & $21 \pm 1$ & $17 \pm 2$ & $28 \pm 1$ \\
\hline Enterococcus faecalis MTCC 439 & $6 \pm 1$ & $12 \pm 1$ & $13 \pm 1$ & $14 \pm 1$ \\
\hline \multicolumn{5}{|l|}{ Clinical Isolates } \\
\hline Enterobacter aerogenes & $7 \pm 1$ & $19 \pm 2$ & $13 \pm 1$ & $22 \pm 1$ \\
\hline Klebsiella pneumonia & $6 \pm 1$ & $14 \pm 1$ & $15 \pm 1$ & $19 \pm 1$ \\
\hline Enterococcus faecalis & $7 \pm 1$ & $15 \pm 1$ & $16 \pm 1$ & $21 \pm 1$ \\
\hline Staphylococcus epidermidis & - & $10 \pm 1$ & - & $16 \pm 1$ \\
\hline Mycobacterium smegmatis & $10 \pm 1$ & $19 \pm 2$ & $16 \pm 1$ & $20 \pm 1$ \\
\hline Escherichia coli & - & $10 \pm 2$ & - & $24 \pm 1$ \\
\hline
\end{tabular}

The values are the average of three different experiments measuring the zone of inhibition $(\mathrm{mm})$

\section{Fluorescence microscope analysis for lipid accumulation in C.elegans}

All worms used in this study were age-synchronized and the experimental animals were grown in liquid M9 medium and raised from eggs obtained by sodium hypochlorite treatment. The extracts of pomegranate fruit peel were made in three different concentrations $(100 \mu \mathrm{g}, 300 \mu \mathrm{g}$, and $500 \mu \mathrm{g} / \mathrm{mL}$ ). They were added to dead OP50 (which were killed by autoclaving) in separate vials. They were then inoculated onto the NGM plates. Twenty worms were inoculated in each plate. Wild-type $C$. elegans were kept for 5 days under various glucose concentrations in the agar prepared as described above, harvested, and washed. Then drop of Nile Red $(0.05 \mu \mathrm{g} / \mathrm{mL})$ solution were added to the worms, which were then incubated for $30 \mathrm{~min}$, washed with $25 \%$ ethanol twice, and photographed in a Fluorescence microscope (Carl Zeiss Axioplan 2).

Table 3 Antifungal activities of crude extracts of Punica granatum (Pomegranate) fruit peel

\begin{tabular}{|c|c|c|c|c|c|}
\hline S. No & Tested fungi & $\begin{array}{l}\text { Hexane } \\
(\mu \mathrm{g} / \mathrm{ml})\end{array}$ & $\begin{array}{l}\text { Ethyl acetate } \\
(\mu \mathrm{g} / \mathrm{ml})\end{array}$ & $\begin{array}{l}\text { Methanol } \\
(\mu \mathrm{g} / \mathrm{ml})\end{array}$ & $\begin{array}{l}\mathrm{Fl} \\
(\mu \mathrm{g} / \mathrm{ml})\end{array}$ \\
\hline 1 & $\begin{array}{l}\text { Curvularia lunata } \\
46 / 01\end{array}$ & 250 & 125 & 125 & 125 \\
\hline 2 & T. rubrum 57/01 & 250 & 31.2 & 125 & 250 \\
\hline 3 & $\begin{array}{l}\text { T. mentagrophytes } \\
66 / 01\end{array}$ & 250 & 31.2 & 125 & 250 \\
\hline 4 & Botrytis cinerea & 250 & 250 & 125 & 250 \\
\hline 5 & Aspergillus flavus & 250 & 31.2 & 125 & 62.5 \\
\hline 6 & $\begin{array}{l}\text { Aspergillus niger } \\
\text { MTCC } 1344\end{array}$ & 250 & 62.5 & 125 & 250 \\
\hline
\end{tabular}

\section{Determination of triglycerides}

Measurement of tryclycerides is used in screening of the lipid status of the worms. In vitro study was performed using ROBIniK Pritest Triglycerides assay kit using the treated C. elegans worms.

\section{Determination of life span}

Synchronized worms were used for life span assay [24]. Twenty number of L4 worms were inoculated in5fluorodeoxyuridine (FUDR40 mM) plate. The worms were grown at desired temperature $\left(25^{\circ} \mathrm{C}\right)$. The worms were scored every day to find out the activity of the plant extracts on them. The unmoved animals were considered as dead.

Table 4 C. elegans Life span assay (Plate contain Glucose) of Punica granatum fruit peel

\begin{tabular}{llc}
\hline Extract & Concentration $(\mu \mathrm{g} / \mathrm{mL})$ & Lifespan (Days) \\
\hline Hexane & 100 & $18 \pm 1$ \\
& 300 & $18 \pm 2$ \\
Ethyl Acetate & 500 & $19 \pm 2$ \\
& 100 & $23 \pm 1$ \\
Methanol & 300 & $24 \pm 2$ \\
& 500 & $25 \pm 2$ \\
& 100 & $20 \pm 1$ \\
Control & 300 & $21 \pm 1$ \\
& 500 & $22 \pm 1$ \\
& 100 & $17 \pm 1$ \\
& 300 & $18 \pm 2$ \\
\end{tabular}

Each value represents the mean \pm SEM of triplicate experiments 


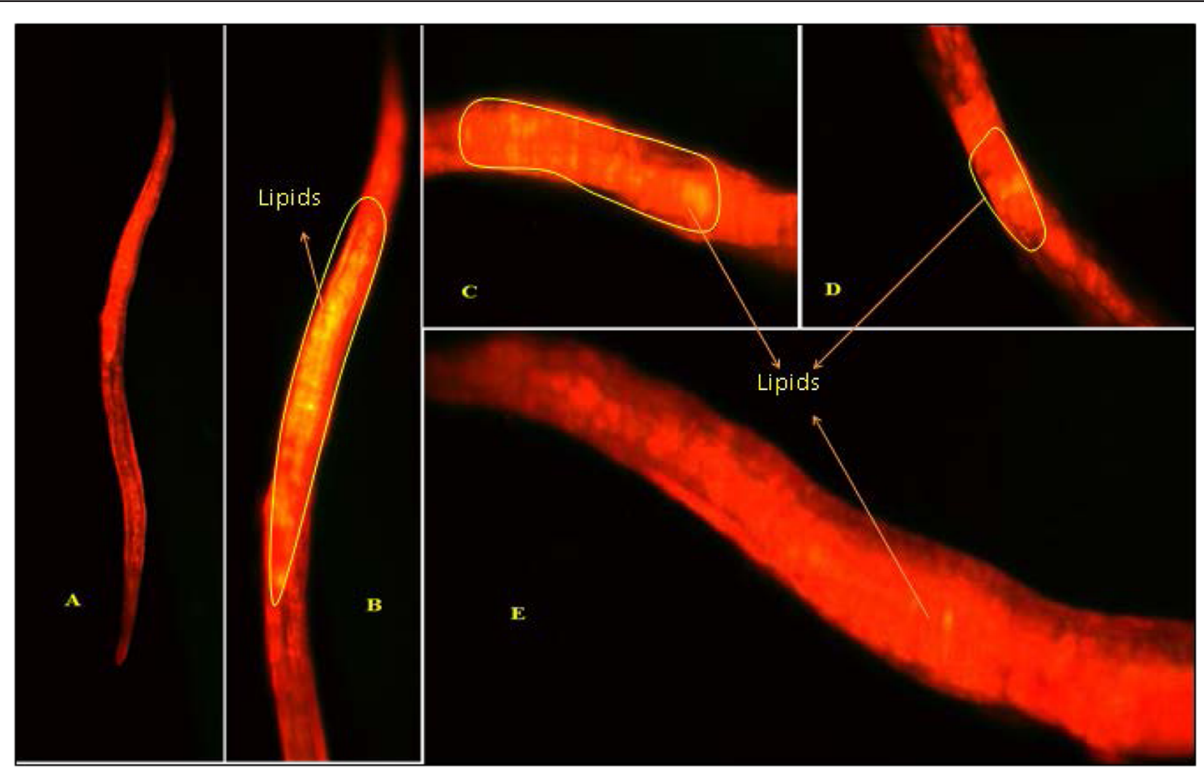

Fig. 5 Lipid accumulation test in C. elegans under fluorescence microscope (Nile Red staining) - a Shows normal C. elegans, b Shows lipid accumulation in C. elegans in the presence of glucose solution, c Shows lipid accumulation in C. elegans in presence of PGPEa extracts extract $(100 \mu \mathrm{g} / \mathrm{ml})$, d Shows lipid accumulation in C. elegans in presence of PGPEa extracts extract (300 $\mu \mathrm{g} / \mathrm{ml})$, e Shows lipid accumulation in C. elegans in presence of PGPEa extracts extract $(500 \mu \mathrm{g} / \mathrm{ml})$

\section{GC -MS analysis}

The individual compounds present in the extract was determined by GC-MS. The standard operating conditions were followed by the reported literature for GC-MS [3].

\section{Statistical analysis}

All the results were analysed in Microsoft Excel 2007.

\section{Results and discussion}

Medicinal plants and their extracts have exploited continuously by researchers in order to produce potential drugs of medicinal properties with reduced toxicity. In the line of this, we reported significant in vitro $\alpha$-glucosidase inhibition activity of ethyl acetate extract of pomegranate peel. The $\alpha$-glucosidase inhibiting potential of solvent extract such as hexane, ethyl acetate and methanol extracts from the fruit peel were tested and the results are summarized in Table 1. Ethyl acetate extract inhibited alpha glucosidase with the maximum value of $75.6 \pm 2.03 \%$ at $500 \mu \mathrm{g} / \mathrm{ml}$ with $\mathrm{IC}_{50}$ value of $285 \pm 1.98 \mu \mathrm{g} / \mathrm{ml}$. Alpha glucosidase inhibiting activity of fruit peel extracts are in the order of ethyl acetate $>$ hexane $>$ methanol.

Pomegranate fruit peel extract potently scavenged DPPH radicals similar to catechin, it is likely that peel extract possessed proton-donating ability and in association with a number of hydroxyl groups to stabilize free radicals $[25,26]$. The results of this study suggest that the extracts contain phytochemical constituents that are capable of donating hydrogen to a free radical. Ethyl acetate extract of pomegranate peel has the ability to reduce the stable radical DPPH to diphenylpicryl hydrazine. The different concentrations of solvent extract of pomegranate peel showed antioxidant activities in a concentration-dependent manner (26-71.2 \%) in the DPPH scavenging assay. Ethyl acetate extract (100$500 \mu \mathrm{g} / \mathrm{ml}$ ) showed the highest activity (30.5-71.2\%). Figure 1 shows the scavenging effects of various extracts

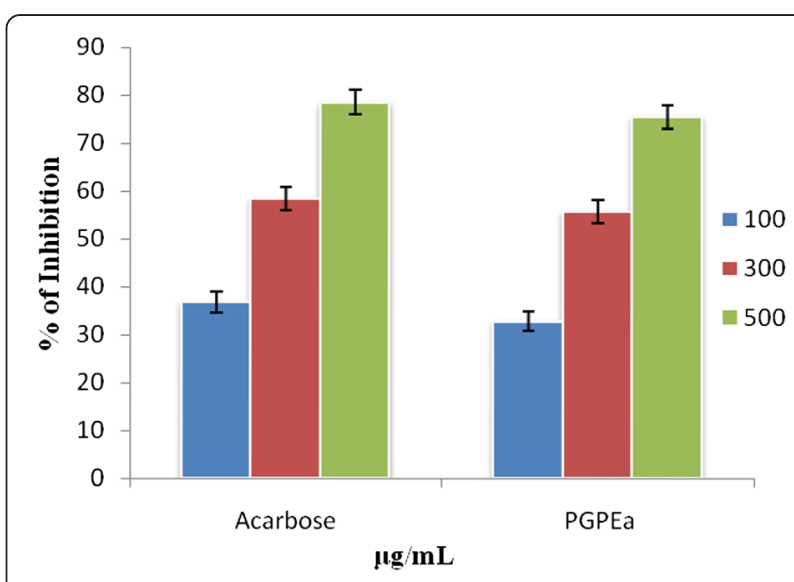

Fig. 6 Lipid Quantification in C. elegans using Triglyceride assay for Punica granatum (Pomegranate) fruit peel extracts 
Table 5 Phytocomponents identified in the ethyl acetate extracts of Punica granatum fruit peel (PGPEa) (GC-MS Study)

\begin{tabular}{|c|c|c|c|}
\hline S. No & Chemical name & Retention time & $\%$ of Area \\
\hline 1 & $\begin{array}{l}\text { 2-furan Carboxamide, N-(3-nitrophenyl)- 1-propanone, } \\
\text { 1-(2-furanyl)-4-Pyridinol }\end{array}$ & 8.266 & 0.60 \\
\hline 2 & $\begin{array}{l}\text { 4H-Pyran-4-one, 3,5-dihydroxy-2-methyl, } \\
\text { 4H-Pyran-4-one, 3,5-hydroxy-2-methyl. }\end{array}$ & 9.425 & 0.62 \\
\hline 3 & $\begin{array}{l}\text { Benzne, 1,3-bis(1,1-dimethylethyl, Benzne, } \\
\text { 1,4-bis(1,1-dimethylethyl }\end{array}$ & 9.552 & 0.31 \\
\hline 4 & 5-hydroxymethylfurfural, 4-fluorobenzyl alcohol & 9.760 & 48.59 \\
\hline 5 & 5-hydroxymethylfurfural, 4-mercaptophenol & 10.242 & 2.99 \\
\hline 6 & 5-hydroxymethylfurfural, 4- fluorobenzyl alcohol & 10.525 & 0.30 \\
\hline 7 & 5-hydroxymethylfurfural, 4-fluorobenzyl alcohol & 10.621 & 0.39 \\
\hline 8 & $\begin{array}{l}\text { Bicycol [7.2.0] undec-4-ene, 4,11,11-trimethyl-8-methylene, } \\
\text { [1R-(1R,4z,9S)]- caryphyllene }\end{array}$ & 12.107 & 0.38 \\
\hline 9 & Hexadecane, 1-iodo- Hexadecane Nonane & 12.902 & 0.59 \\
\hline 10 & Z-8- Hexadecane, 9-Eicosene, (E)- n-Pentadecanol & 14.321 & 0.14 \\
\hline 11 & Copaene, alpha. Cubebene & 14.989 & 0.29 \\
\hline 12 & Hexadecane, 2-Bromotetradecane & 15.420 & 0.90 \\
\hline 13 & Heneicosane, 11-pentyl-Docosane, 11-butyl-Tridecane & 15.561 & 0.54 \\
\hline 14 & Nonadecane, 9-methyl-Nonane, 5-butyl-Heptadecane & 15.911 & 0.27 \\
\hline 15 & Z-8-Hexadecane, Pentafluropropinonic acid, 4-hexad ecyl ester & 16.535 & 0.94 \\
\hline 16 & Heneicosane, Eicosane & 17.649 & 0.63 \\
\hline 17 & $\begin{array}{l}\text { Nonadecane, 9-methyl, 7,9-Di-tert-butyl-1-oxaspiro }(4,5) \\
\text { deca-6,9-diene-2,8-dione. }\end{array}$ & 17.731 & 0.68 \\
\hline 18 & $\begin{array}{l}\text { Pentadecanoic acid, 14-methyl easter, Hexadecanoic } \\
\text { acid, methyl easter }\end{array}$ & 17.939 & 0.81 \\
\hline 19 & Nonadecane, 9-methyl, Eicosane, Pentacosane & 18.080 & 0.34 \\
\hline 20 & 1-heneicosyl formate, Cyclooctacosane, 9-Tricosen, (Z)- & & \\
\hline 21 & Tetracosane, Octodecane, Hexadecane & 19.543 & 0.48 \\
\hline 22 & Triacontane, 1-bromo-1-Chloroeicosane Heptadecane & 19.595 & 0.59 \\
\hline 23 & Dodecane, 2,6,11-trimethyl-docosane, 7-hexyl-Tetracosane & 19.677 & 1.98 \\
\hline 24 & $\begin{array}{l}\text { Linoleic acid ethyl ester n-Propyl 9, 12-octadecadienoate } \\
\text { 9, 12-octadecadienoic acid, ethyl ester }\end{array}$ & 20.137 & 0.53 \\
\hline 25 & 1-nonadecene, 9-Trocosene, (Z)- Bacchotricuneatin & 20.204 & 0.63 \\
\hline 26 & 1-nonadecene, 9-Trocosene, Z-5- Nonadecene & 20.412 & 0.71 \\
\hline 27 & Tetracosane, Octadecane, Heptadecane & 20.457 & 0.50 \\
\hline 28 & $\begin{array}{l}\text { 6-octen-1-ol, 3,7-dimethyl acetate Phytol, acetate } \\
\text { 1,2-15, 16-Diepoxyhexadecane }\end{array}$ & 20.583 & 2.02 \\
\hline 29 & $\begin{array}{l}\text { 3,5,7-Tricyclopropyl-5,6-dihydro-5-methyl-1,2 } \\
\text { (4H)-diazepineOctanoic acid, but-3-yn-2-yl ester Ethisterone }\end{array}$ & 20.888 & 1.14 \\
\hline 30 & Triacontane, Heptadecane, Octacosane & 21.333 & 0.39 \\
\hline 31 & $\begin{array}{l}\text { 3H-Cyclodeca[b]furan-2-one, 4, 9-dihydroxy-6-methyl-3, } \\
\text { 10-dimethylene-3a, 4, 7, 8, 9, 10, 11, 11a-octahydro-Bicyclo } \\
\text { [10.1.0]trideca-4, 8-diene-1 3-carboxamide, } \\
\text { N-(3-chlorophenyl)-1H-2, 8a-Methanocyclopenta[a] } \\
\text { cyclopropa[e]cyclodecen-11-one, 1a, 2, 5, 5a, 6, 9, 10, } \\
\text { 10a-octahydro-5, 5a, 6-trihydroxyl-1, 4-bis(hydroxymethyl)-1, } \\
\text { 7, 9-trimethyl, [1S-(1.alpha., 1a.alpha., 2.alpha., 5.beta., } \\
\text { 5a.beta., 6.beta., 8a.aipha., 9.alpha., 10a.alpha.)] }\end{array}$ & 21.437 & 0.83 \\
\hline 32 & Heptadecane, 3-methyl- OctadecaneNonadecane & 21.512 & 1.41 \\
\hline 33 & Octacosane, Tetracosane & 22.165 & 0.81 \\
\hline 34 & Eicosane, Triacotane, Octadecane & 22.975 & 0.42 \\
\hline
\end{tabular}


Table 5 Phytocomponents identified in the ethyl acetate extracts of Punica granatum fruit peel (PGPEa) (GC-MS Study) (Continued)

\begin{tabular}{|c|c|c|c|}
\hline 35 & Hexatriacontane, Octadecane, 1-iodo-Tetratetracontane & 23.205 & 0.37 \\
\hline 36 & 1-hexacosene, 9-hexacosene, E-15-heptadecenal & 23.725 & 0.37 \\
\hline 37 & Squalene & 25.300 & 1.07 \\
\hline 38 & Eicosane, Heneicosane, & 25.924 & 0.56 \\
\hline 39 & $\begin{array}{l}\text { Vitamin E (+)-gamma- Tocopherol, } \\
\text { O-methyl-dl-alpha.- Tocopherol }\end{array}$ & 27.499 & 0.96 \\
\hline 40 & $\begin{array}{l}\text { CyclobarbitalTris(tert-butyldimethylsilyloxy)arsane, } \\
\text { 1H-Indole-2-carboxylic acid, 6-(4- ethoxyphenyl)-3-methyl-4-oxo-4, } \\
\text { 5, 6, 7-tetrahydro isopropyl ester }\end{array}$ & 27.573 & 0.41 \\
\hline 41 & $\begin{array}{l}\text { 2, 4-Cyclohexadien- 1-one, 3, 5-bis, 1-dimethylethyl)- } \\
\text { 4-hydroxy- Tetrasiloxane, decamethyl- Benz[b]-1, } \\
\text { 4-oxazepine-4(5H)-thione, } \\
\text { 2, 3-dihydro-2, 8-dimethyl }\end{array}$ & 28.695 & 0.69 \\
\hline 42 & $\begin{array}{l}\text { Anthracene, 9, 10- dihydro-9, 9, 10-trimethyl-1H- Indole, } \\
\text { 1-methyl-2-phenyl-Ethanone, 2-(2-benzothiazolylthio)-1-(3, 5-dimethylpyralyl) }\end{array}$ & 29.082 & 1.52 \\
\hline 43 & $\begin{array}{l}\text { N-Methyl-1-adamantaneacetamide Arsenous acid, tris(trimethylsilyl) } \\
\text { ester, Benzo[h]quinolone, 2, 4-dimethyl }\end{array}$ & 29.275 & 0.69 \\
\hline 44 & 9, 19-cyclolanost-24-en-3-ol, Lanosterol, Lanost-7-en-3-one & 29.512 & 7.37 \\
\hline 45 & Tirucallol, Lanosterol, D:B-Friedo-18, 19-secolup-19-ene, 10-epoxy & 29.943 & 7.58 \\
\hline 46 & $\begin{array}{l}\text { 1, 2-Bis(trimethylsilyl) benzene, 4-Dehydroxy-N-(4, 5-methylenedioxy- } \\
\text { 2-nitrobenzylidene) tyramineBenzo[h]quinolone, 2, 4-dimethyl }\end{array}$ & 30.382 & 1.48 \\
\hline 47 & $\begin{array}{l}\text { 1H-Indole, 1-methyl-2-phenyl- Arsenous acid, tris(trimethylsilyl) } \\
\text { ester, Cyclotrisiloxane, hexamethyl }\end{array}$ & 30.864 & 0.86 \\
\hline 48 & $\begin{array}{l}\text { 5-methyl-2-phenylindozine (1H) Pyrrole-3-carboxylic acid, } \\
\text { 5-[cyano(4-morpholinyl) methyl]-1-(methoxymethyl), } \\
\text { methyl ester 2-(Acetoxymethyl)-3-(methoxycarbonyl) biphenylene }\end{array}$ & 31.533 & 1.06 \\
\hline
\end{tabular}

of pomegranate fruit peel on $\mathrm{DPPH}^{\cdot}$ in the following order: ethyl acetate $>$ methanol $>$ hexane.

The total antioxidant capacity of various solvent extracts of pomegranate fruit peel at different concentrations $(100-500 \mu \mathrm{g} / \mathrm{ml})$ was found to be in the following order: ethyl acetate $>$ methanol $>$ hexane (Figs. 2, 3 and 4). Ethyl acetate extract $(500 \mu \mathrm{g} / \mathrm{ml})$ showed the highest total antioxidant activity (69.5\%).

The antibacterial activity of $P$. granatum fruit peel may be because of the presence of metabolic toxins or broad spectrum antimicrobial compounds that act against both Gram + ve and Gram -ve bacteria. The results of antibacterial activity of ethyl acetate extract of $P$. granatum (Pomegranate) fruit peel (PGPEa) against various human pathogens are listed in the Table 2. The MIC was significantly lower in ethyl acetate extracts that inhibits $T$. rubrum and T. mentagrophytes $(31.25 \mu \mathrm{g} / \mathrm{ml}$ ) (Table 3$)$.

Various investigations were carried out to determine antioxidant, anticarcinogenic, and anti-inflammatory properties of pomegranate constituents [27-29]. Hajoori et al. [30] evaluated the antibacterial activity of different solvent extracts of $P$. granatum peel against human pathogens including four gram positive bacteria and six gram negative bacteria. According to Rathi et al. [31] $P$. granatum fruit peel can be used as an easily accessible source of natural antioxidant. They clearly demonstrated broad spectrum antimicrobial activity of pomegranate against bacteria. Additionally they mentioned that the presence of phytocompounds in the extracts including phenols, tannins and flavonoids as major active constituents may be responsible for these activities. Thus, the present study provides a strong direction for proper investigation of pomegranate fruit peel to explore molecules having antimicrobial properties against human pathogens. The presence of active inhibitors in pomegranate fruit peels including phenolics and flavonoids were revealed by phytochemical analysis as potent constituents.

The observed lifespan of $C$. elegansas model organism (control) was about $17 \pm 1$ days and the normal worms about $25 \pm 1$ days sillar to the other reported study [32]. When the observed result of the control was compared with that of the tests, we found that the ethyl acetate extract of $P$. granatum fruit peel showed the increased lifespan of the worms than that of the control i.e., about 24 \pm 1 days. The second highest activity was shown for methanol extract of P. granatum (Table 4).

C. elegans provides a reliable tool to understand the changes in lipid accumulation in the body by glucose concentrations that are within the range observed in poorly controlled diabetic patients [33]. In the present 
study ethyl acetate extract of pomegranate fruit peel has the ability to reduce the lipid accumulation in the worm body. The fluorescence microscopic analysis clearly shows that ethyl acetate peel extract treated worms have accumulated less lipid compared to the normal worms (Figs. 5 and 6). Reduction in glucose level and lipid content in C.elegans indicates that ethyl acetate extract of pomegranate fruit peel has potential antidiabetic compounds which need to be isolated and identified through chromatographic techniques. Undoubtly ethyl acetate extracts of the test plant showed the presence of diverse molecules when subjected to GC-MS. In PGPEa a total of 48 compounds were detected, out ofwhich the maximum area was found for 5-hydroxymethylfurfural and 4-fluorobenzyl alcohol (Table 5) with a value of 48.59 \% (Fig. 7).

\section{Conclusion}

It is concluded that the ethyl acetate extract of pomegranate fruit peel contained considerable levels of phenols and flavonoids which are responsible for $\alpha$ glucosidase inhibition and antioxidant activities. These in vitro assays also indicate that the PGPEa not only has potential antidiabetic and natural antioxidant compounds but also has the ability to increases the life span of C. elegans. Future studies are required to prove whether the process described in C. elegans can be translated to the situation in diabetic patients. 5hydroxymethylfurfural and 4-fluorobenzyl alcohol compounds detetcted in GCMS might plaied the role in antioxidant and antimicrobial potentials of the extracts.

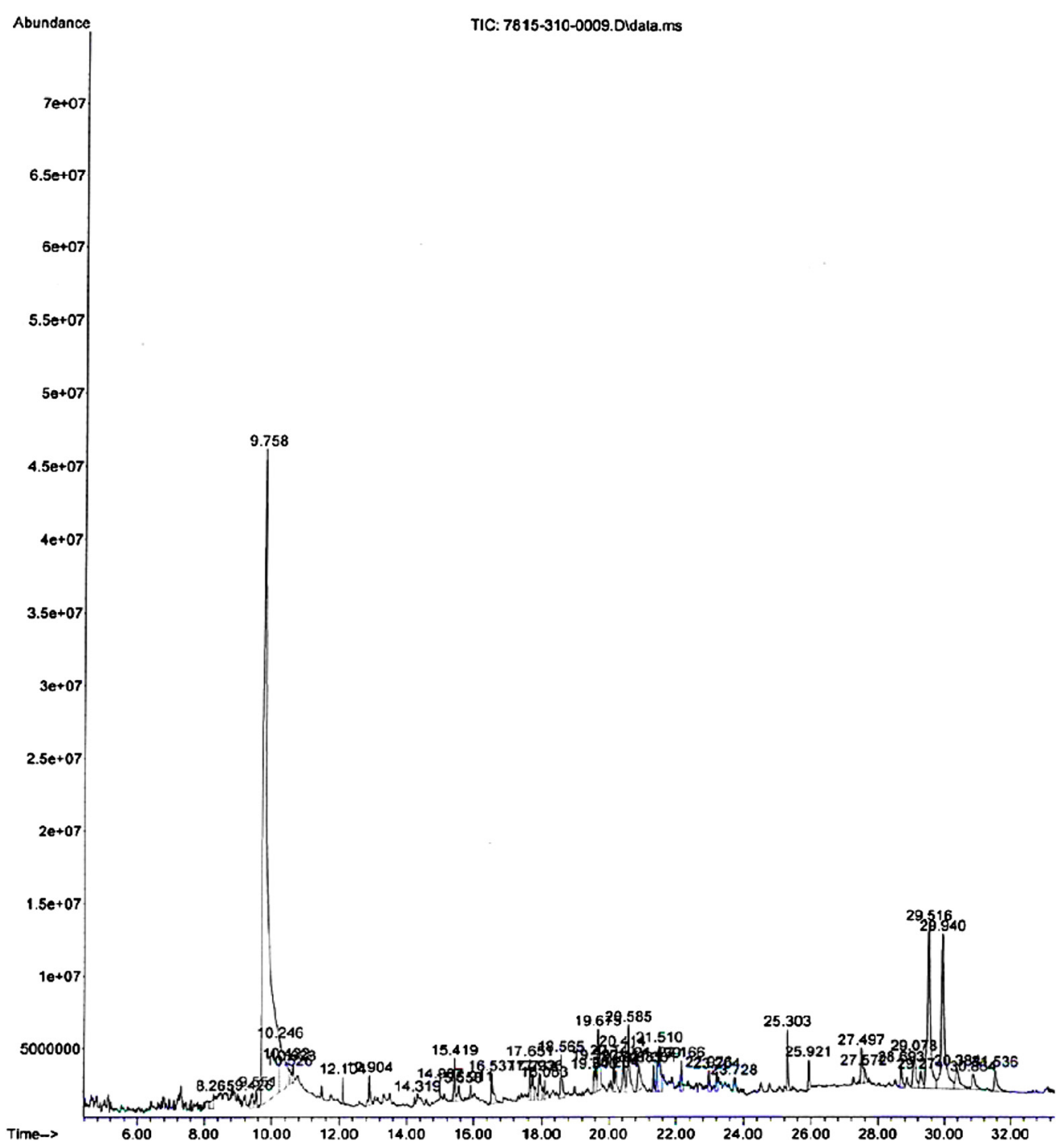

Fig 7 GC - MS Chromatogram of Ethyl acetate extracts of Punica granatum fruit peel extracts. 5-hydroxymethylfurfural and 4-fluorobenzyl alcohol metabolites were found to be most biologically active components (based upon the retention time) present in the crude extract 


\section{Abbreviations}

GC-MS, gas chromatography-mass spectrometry

\section{Acknowledgement}

We would like to thank Department of Biotechnology, India (Indo-Spain Collaborative project, Ref. No. - BT/IN/Spain/19/PA/2013) for financial assistance. This study was supported by grants from the Cooperative Research Program for Agriculture Science \& Technology Development (Project No. PJ0102212014), Rural Development Administration, Korea. The authors extend their sincere appreciation to the Deanship of Scientific Research at King Saud University for its funding this Prolific Research Group (PRG-1437-28).

\section{Availability of data and materials}

All data and materials were given in the manuscript. We have further data and materials.

\section{Authors' contributions}

$\mathrm{KBK}, \mathrm{BV}$ and $\mathrm{AK}$ carried out the experimental part of the manuscript. KBK, NAA-D, $B V$, AK and MVA analyzed the antimicrobial, antioxidant and in vivo studies. KBK, MVA, HSC, and PA participated in its design and coordination and helped to draft the manuscript. HSC, YOC and PA involved in analyzing and monitoring the data and experiment. All authors read and approved the final manuscript.

\section{Competing interests}

The authors declare that they have no competing interests.

\section{Consent for publication}

Not applicable.

\section{Ethics approval and consent to participate}

Not applicable.

\section{Financial disclosure}

India (Indo-Spain Collaborative project, Ref. No. - BT/IN/Spain/19/PA/2013); South Korea (Project No. PJ0102212014), Saudi Arabia (PRG-1437-28).

\section{Author details}

'Ethanopharmacology and Microbial Biotechnology Unit, Research Department of Plant Biology and Biotechnology, Loyola College, Nungambakkam, Chennai 600034, India. ${ }^{2}$ Department of Botany and Microbiology, Addiriyah Chair for Environmental Studies, College of Science, King Saud University, Riyadh 11451, Saudi Arabia. ${ }^{3}$ Department of Emergency Medicine, College of Medicine, Kyung Hee University, Seoul 02447, Republic of Korea. ${ }^{4}$ Development of Ginseng and Medical Plants Research Institue, Rural Administration, Eumseong 369-873, Republic of Korea.

Received: 5 January 2016 Accepted: 21 July 2016

Published online: 30 July 2016

\section{References}

1. Sharma AK. In: Sharma AK, editor. Diabetes mellitus and its complications: An update. 1st ed. New Delhi: Macmillan India Ltd; 1993. p. 92-205.

2. Piedrola G, Novo E, Escober F, Garcia-Robles R. White blood cell count and insulin resistance in patients with coronary artery disease. Ann Endocrinol. 2001:62(1):7-10

3. Glorybai L, Kannan KB, Arasu MV, Al-Dhabi NA, Agastian P. Some biological activities of Epaltes divaricata L. - anin vitro study. Ann Clin Microbiol Antimicrob. 2015;14(18):1-11.

4. Balamurugan R. Smilax chinensis Linn. (Liliaceae) root attenuates insulin resistance and ameliorate obesity in high diet induced obese rat. South Ind J Biol Sci. 2015;1:47-51.

5. Vigouroux C, Caron-Debarle M, Le Dour C, Magre J, Capeau J. Molecular mechanisms of human lipodystrophies: from adipocyte lipid droplet to oxidative stress and lipotoxicity. Int J Biochem Cell Biol. 2011;43(6):862-76.

6. Sztalryd C, Kimmel AR. Perilipins: lipid droplet coat proteins adapted for tissue-specific energy storage and utilization, and lipid cytoprotection. Biochimie. 2014;1:96-101.

7. Mahboubi A, Asgarpanah J, Sadaghiyani PN, Faizi M. Total phenolic and flavonoid content and antibacterial activity of Punica granatum L. var. pleniflora flowers (Golnar) against bacterial strains causing foodborne diseases. BMC Complement Altern Med. 2015;15(1):1.
8. Dastjerdi EV, Abdolazimi Z, Ghazanfarian M, Amdjadi P, Kamalinejad M, Mahboubi A. Effect of Punica granatum L. flower water extract on five common oral bacteria and bacterial biofilm formation on orthodontic wire. Iran J Public Health. 2014;12:1688

9. Li Y, Guo C, Yang J, Wei J, Xu J, Cheng S. Evaluation of antioxidant properties of pomegranate peel extract in comparison with pomegranate pulp extract. Food Chem. 2006;96(2):254-60.

10. Antonisamy P, Duraipandiyan V, Ignacimuthu S, Kim JH. Anti-diarrhoeal activity of friedelin isolated from Azima tetracantha Lam. in Wistar rats. South Ind J Biol Sci. 2015;1:34-7.

11. Middleton E, Kandaswami C, Theoharides TC. The effects of plant flavonoids on mammalian cells: Implication for inflammation, heart disease and cancer. Pharmacol Rev. 2000;52(4):673-81.

12. Lobo V, Patil A, Phatak A, Chandra N. Free radicals, antioxidants and functional foods: Impact on human health. Pharmacogn Rev. 2010:4(8):118-26.

13. Simoes $\mathrm{M}$, Bennett RN, Rosa EA. Understanding antimicrobial activities of phytochemicals against multidrug resistant bacteria and biofilms. Nat Prod Rep. 2009;26(6):746-57.

14. Rangasamy K, Namasivayam E. In vitro Antioxidant and Free Radical Scavenging Activity of Isolongifolene. Asian J Biol Sci. 2014;7(1):13-23.

15. Suzuki M, Shinohara Y, Ohsaki Y, Fujimoto T. Lipid droplets: size matters, J Electron Microsc. 2011;60(1):S101-16.

16. Shi X, Li J, Zou X, Greggain J, Rodkaer SV, Faergeman NJ, Liang B, Watts JL. Regulation of lipid droplet size and phospholipid composition by stearoylCoA desaturase. J Lipid Res. 2013;54(9):2504-14.

17. Martin S, Parton RG. Lipid droplets: A unified view of a dynamic organelle. Nat Rev Mol Cell Biol. 2006;7(5):373-8

18. Farese RV, Walther TC. Lipid droplets finally get a little R-E-S-P-E-C.-T. Cell. 2009;139(5):855-60.

19. Dahlqvist A. Method for assay of intestinal disaccharidases. Anal Biochem. 1964;7(1):18-25.

20. Nimal Christhudas IVS, Praveen Kumar P, Sunil C, Vajravijayan S, Lakshmi Sundaram R, Jenifer Siril S, Agastian P. In vitro studies on a-glucosidase inhibition, antioxidant and free radical scavenging activities of Hedyotis biflora L. Food Chem. 2013;138:1689-95.

21. Hatano T, Kagawa H, Yasuhara T, Okuda T. Two new flavonoids and other constituents in licorice root: Their relative astringency and radical scavenging effects. Chem Pharm Bull. 1988;36(6):1090-2097.

22. Roa KS, Nargesh KK, Ravi KBW. A comparative study of polyphenoliccomposition and in vitro antioxidant activity of Illicium verum extracted by microwave and soxhlet extraction techniques. Ind J Pharm Educ. 2012:46(3):228-34.

23. Clinical and Laboratory Standards Institute (CLSI). Reference method for broth dilution antifungal susceptibility testing of yeasts. In: Approved Standard. 3rd ed. Wayne: CLSl; 2008. p. M27-A3.

24. Sutphin GL, Kaeberlein M. Measuring Caenorhabditis elegans life span on solid media. J Vis Exp. 2011;49:2496.

25. Nair RK, Haridas A, Ezhuthupurakkal DR. Diversity and comparative account on phytochemical and antioxidant properties of two varieties of Musa, Nendran and Kunnan. South Ind. J Biol Sci. 2016:2(1):203-6.

26. Brand-Williams W, Cuvelier M, Berset C. Use of a free radical method to evaluate antioxidant activity. Lebensm-Wiss Technol. 1995;28(1):25-30.

27. Noorudheen N, Chandrasekharan DK. Effect of ethanolic extract of Phyllanthus emblica on captan induced oxidative stress in vivo. South Ind J Biol Sci. 2016;2:95-103.

28. Adhami VM, Khan N, Mukhtar H. Cancer Chemoprevention by Pomegranate: Laboratory and Clinical Evidence. Nutr Cancer. 2009;61(6):811-5.

29. Al-Zoreky NS. Antimicrobial activity of pomegranate (Punica granatum L.) fruit peels. Int J Food Microbiol. 2009:134(3):244-8.

30. Hajoori M, Naik M, Naik K, Desai S. Evaluation of antimicrobial activity of Punica granatum peel extracts using different solvent system. Int J Pharmacol Screen Methods. 2014;4(1):26-31.

31. Rathia P, Rajput CS, Singhal S. Evaluation of total phenolic contents, antioxidant and antibacterial capacity of aqueous methanolic extracts obtained from Punica granatum peel. Int J Pharm Sci Rev Res. 2014:25(2):92-4.

32. Rathi MA, Meenakshi P, Gopalakrishnan VK. Hepatoprotective activity of ethanolic extract of Alysicarpus vaginalis against nitrobenzene-induced hepatic damage in rats. South Ind J Biol Sci. 2015;1 (2):60-5.

33. Schlotterer A, Kukudov G, Bozorgmehr F, Hutter H, Du X, Oikonomou D, et al. C. elegans as Model for the Study of High Glucose-Mediated Life Span Reduction. Diabetes. 2009;58(11):2450-6. 